\title{
Correlations Between Corporate Governance Practices And Financial Performances In Indian Banks
}

\author{
A.Saraswathy
}

\begin{abstract}
In the last era, Corporate Governance has advanced and developed significantly. Integration and globilisation of the capital markets and financial markets are the important factors for the rapid developments in this arena. It has also made way to the development of more number of corporate scandals (such as corporate accounting scandal at Satyam computer services) or fraud loans by Banks (Punjab National Banks).The study based on correlation, analyses the link between corporate governance disclosure practices and the financial ratios, which in turn leads to a successful governance paradigm accountability. It also aims to study about the financial ratios, which are within the RBI trigger level and find out whether there is any correlation between the movements of share prices and earnings per share of the banks during the study period.
\end{abstract}

\section{INTRODUCTION}

The system of Corporate Governance controls and directs Business entities. It is a procedure or a set of methods and practices to ensure that a company is managed to suit the best interest of all. It is concerned with accountability of persons who are managing it towards the stakeholders. Corporate governance is concerned with the morals, ideals, parameters, principles, behaviour and conduct of the concern and its management. Corporate governance is a voluntary ethical code of the business of organisations and ensures that this system may contain organisational and structural matters. In United Kingdom, there was a serious concern and growing awareness in the business and trading community that the system of corporate mechanism was not well. Many companies to increase their earnings and accelerate their growth, found the loopholes in the accounting systems and standards to understate liabilities and boost their profits exploited the weakness of the accounting standards and consequently it was more evident from the deficiencies in the accounting standards. Accounting controls went fuddled while companies grew remarkably. On the other side unwanted interference in the day-to-day management from outside directors, gradually resulted in change in Board structures. By the end of the 1980's several companies, collapsed, leading to expression of concern on the issue of "corporate governance'. The two main concerns at that time were:

-Too much power in one individual

-Inadequacy of operating control within the companies, which were otherwise fundamentally wrong.

Revised Manuscript Received on April 19, 2019.

Dr. A.Saraswathy, Associate Professor, Department Of Commerce, GAC, Nandanam, Chennai, Tamilnadu, India. (Email: sss_saraswathy@yahoo.com)
In all the corporate/ban crimes recently surfaced in India and around globe, the institutional nominees on the Board have played a passive role and in most cases, have tended to vote with the incumbent management.

\section{CORPORATE GOVERNANCE IN INDIA}

Corporate governance practices are evaluated based totally on Board practices, disclosures, and transparency of information provided via the use of the corporate entities. In the overdue Nineteen Nineties, a reform approach has started to develop the modern day requirements for disclosures of enterprise governance practices in India. Corporate governance plays a crucial feature for banks and monetary institutions. They provide financial services to a maximum good sized phase of the society and offer to finance for industrial agencies. Banks deal with the public or in any other case people fund and want to be trustful for depositor's money consequently. During the 1990s, LPG new monetary coverage in India, unleashed a process of liberalization and deregulation and hence, personal zone banks entered into the Indian Banking place. The involvement of the primary private region financial institution in the stock marketplace rip-off has circulated the wrong belief that non-public sector banks are a version of pinnacle governance. So, RBI and Government of India acknowledged the vulnerability of depositors to the whims of managerial mishaps in banks and therefore have been bearing on banks more forcefully then unique sectors. Moreover, some monetary group failures inside the Western countries emphasized the need for close to shadowing of the banking device both inside the U.S.A And globally.

Cadbury Committee commented on economic factors of Corporate Governance: "It is the device by using which organizations directed and managed. The Board of Directors is answerable for the disclosures and transparency for Governance in their businesses. In the Governance, the shareholders' function is to rent the Auditors and the Directors and to fulfill themselves that the correct Governance shape is within the vicinity".Shri Kumar Mangalam Birla defined Corporate Governance as "the fundamental aim of Corporate Governance is the 'enhancement of the lengthy-term shareholder fee while at the equal time shielding the hobbies of different

stakeholders. "There may be impact on the overall power 
of the banking tool pondered in the form of upsurge in business

enterprise stages, ebook values of the securities/stocks, capitalization of the marketplace, dividends declared, profitability or internet surely really worth, turnover ratios or profitability ratios, etc., if Corporate Governance implemented in totality in banks. After the adoption of Corporate Governance practices in banks has begun to reflect adjustments in their increase sample and the style of governance. There is a better correlation with the coverage of corporate governance measures with the capital market, and those segments will even attempt to quantify the performance of banks.

\section{CORPORATE GOVERNANCE AND RBI}

Banks are the most challenge of the governing authorities to guard and guard the problematic money of bank depositors. The whole financial system of a country is through the Banking region due to its linkage with different sectors. It plays a critical function in developing nations that are now remodeling from agriculture-based financial system to enterprise-based economy. Banking region, which is the largest unit of the fiscal quarter, banks ought to function at its first-rate with utmost performance to contribute within the monetary development of the USA. Any United States of America's improvement might spoil a long time if there is any shortfall or even a mild instability in the Banking region. For powerful and efficient banking machine for any USA calls for the presence of complete corporate governance and its suitable practices.

Mandatory banking Disclosures by RBI are:

1. Disclosure score on Balance Sheet items.

2. Disclosure score on Profit and Loss Account items.

3. Disclosure score on Director's Report.

4. Disclosure score on Management Discussion and Analysis Report.

5. Disclosure on Corporate Governance.

6. Disclosure score on RBI Guidelines.

7. Disclosure regarding committees.

Corporate Governance function was performed by the Reserve Bank of India with the guidance of the Board of Financial supervision. Consolidated supervision of the financial sector was undertaken by this Board. Reserve Bank of India follows three approaches for Corporate Governance device are:

a) Two main pillars of a Corporate Governance are Disclosures and Transparency. It assists the stakeholders and prominent institutions with adequate and sufficient information consisting important and informed decisions.

b) Off-site scrutiny tool observes the assets and its movement, the capital sufficiency and its impact and overall competence and acceptability of management practices.

c) Capital Adequacy ratio, Non-Performing Assets Ratio and Return on Assets ratio are the three parameters with which effective banking administration and management are executed through the supervisory tool prompt corrective action. Published balance-sheet, off-site returns and on-site inspection reports are the primary sources for these actions.

Other Corporate Governance Mechanisms a. SEBI, under clause 49, governs listed banks, Nonbanking finance companies and other financial

intermediaries.

b. RBI has issued various notifications and circulars that provide guiding principles on

- Remuneration, qualification, composition and independence of Board of Directors.

- Responsibilities, training and roles of Executive Directors.

- Constitution of Risk management, Audit Committee and Nomination committee.

\section{CORPORATE GOVERNANCE AND FINANCIAL RATIOS}

The impact of Corporate Governance in Banks, its implementation effect, consequently rise in business levels, increase or growth in net worth, increase in earnings per share or book values of the shares, upsurge in profitability ratios, expansion in market capitalisation etc., can be studied through financial ratios. Financial ratios are the pointers to evaluate performance of the business entities during a period of time. Income statement or Balance sheet are the basis for the financial ratios and accountants or researchers can compute the required ratios and they can describe the capital, profitability and structures of the business entities.

\section{NEED OF THE STUDY}

In the current competitive scenario, not only accounting frauds and financial camouflage are in increasing occurrence, but also its nature and consequences of frauds are far from its understandability. It is then essential to investigate the nature of fraud, what factors motivated or influenced the frauds, how the corporate mechanisms can be utilised to discover such fraudulent activities and the ways to end it. The present paper finds a solution to the problems faced by the banks and suggest some assurance measures to the bank customers and depositors.

\section{OBJECTIVES}

The objective of the study is to identify any relationship between corporate governance and financial

performance of selected banks in India. It hopes to find out whether

(a) To examine the disclosure practices of the selected banks during the study period.

(b) There is any relationship between the corporate governance disclosures and key financial ratios of the selected banks during the study period.

(c) Whether the selected banks have been able to maintain the financial ratios within trigger.

(d) Whether, the movements reflects in the share prices and earnings per share of the selected banks.

\section{METHODOLOGY}

This study relied on secondary data. The source for the data was the NSE data from the year 2013 to 2017. From the 
site NSE data sources, Financial Report, Audit Committee, Composition of Board of Directors, Meetings of Board of Directors, and Meetings of Committees details were studied. The systematic sampling approach was used to select the banks. The sample consists of three Nationalised banks- State Bank of India, Canara Bank and Indian Bank, one Industrial development bank - Industrial Development Bank of India and two private sector banks - ICICI and HDFC based on capitalization. For Financial ratios, RBI website is the data source for the study.

\section{REVIEW OF LITERATURE}

Twenty four Governance rules with constructed "Governance Index" for about 1,500 large firms studied by Gompers, Ishii and Metrick (2003) to proxy the levels and rights of the stakeholders. The study also provided information about the investment strategy that sold the firms in the highest decile of the index and bought firms in the lowest decile of the index - strongest rights. It added that the firms would have earned abnormal returns of 8.5 percent per year. They found that firms with stronger shareholder rights had higher firm value, greater profits, greater sales growth, lower capital expenditures, and made less corporate acquisitions.

The purpose of the paper published by Riccardo Tiscini Francesca di Donato (2004) is to analyse the relation between corporate governance systems and financial frauds typologies. The first authentication on empirical significance of the distinction between a model of "performance stress" accounting fraud and a model of "excessive power" accounting fraud was hypothesised. This study has also given the first confirmation on empirical relevance of the hypothesis that corporate governance systems influence the way in which accounting frauds are committed.

Spong and Sullivan (2007), in their article discussed about how different aspects of corporate governance influences bank performance. They also initiated that Boards of Directors are expected to have more constructive effect on community bank performance when directors have a foremost monetary attention in the bank. Finally, they further studied that the prosperity and the financial positions of managers and directors expressively have impact on their own attitudes towards risk-return trade-offs of their banks and towards their risk-taking aspects.

Norhafiza, and Ibrahim (2007) attempted to discuss about the relationships between the important Balance ratios and disclosures meant in Corporate Governance among the listed companies of Malaysia and found that there is association between the two, disclosures and ratios.

Mbanwie (2009) in his study examined about the ratios which are most significant and consistent ratios for forecasting bankruptcy. The empirical results indicate that the ratios of total sales-total assets and total sales-credit sales are not related to financial distress. Quick ratio, net profit-total assets, long-term debt-total equity and operating profit-turnover are the four most noteworthy distinct bankruptcy indicators. The study period was from 1996 to 2003 and used for analysis the financial reports of groups of bankruptcy in Swedish and other active business firms
According to Jonathan R. Macey and Maureen O'Hara (2009)during bankruptcy directors should consider the interests of fixed claimants over those of shareholders. The need for protecting the interest of fixed claimants is far more profound in banking. In the second part, they studied about the obligation of Directors and their duties to provide continuous oversight of the business firms on whose Boards they work. Lastly, they found that the new financial regulatory environment, which was envisioned by the Gramm-Leach-Bliley Act, are enhanced standards and they are concordant.

Dr. Gursharan and Jyoti Agnihotri (2012) provided a detailed study on the disclosure practices in banking sector of India in their paper. The study concluded that the monetary, financial and quantifiable information generated need to be conversed to the stakeholders in an effective manner and through suitable medium such as financial statements, ensuring transparency and appropriateness. The paper also discussed about the financial statements which is facilitated by a well laid out system of accounting.

In an another paper by Kar (2014) , study has been conducted on the major issues such as rights and disclosure of information, board issues, disclosure and transparency, human resource management and financial reporting. Seven hypothesis have been framed in order to find whether the banks in Bangladesh are complying with corporate governance practices or not. The study studied was based on private banks of Bangladesh. But according to the study most of the issues like financial reporting, disclosure and transparency, auditing practices have met the hypothesis.

After the collapse of few gigantic firms, Corporate Governance became an area of massive interest and urged one. Mahmood, R., \& Islam, M. (2015) portraits about Hallmark Group made a BDT 4000 crore scam. The study found that in the banks of Bangladesh, Corporate Governance practices less in number and thus there are more number of fraudulent activities have arisen. However, this study was instigated to critically detect the current Corporate Governance prominence and practices in the banks of Bangladesh.

The aim of the paper published by Liang, Lu, Tsai, \& Shih, (2016) is to assess the prediction performance obtained by combining seven different categories of Financial Reports and five different categories of Corporate Governances. The study show that the profitability and solvency ratios calculated with these disclosures are the most significant features for the happening of bankruptcy. However, these findings may not be applicable in some markets.

\section{DATA ANALYSIS AND INTERPRETATION -I}

\section{Corporate Governance Disclosures}

The primary objective of the study is to establish the corporate governance practices of the selected banks during the study period and also to find out that the corporate governance disclosures were adequate, i.e. according to RBI, whether the selected banks discloses the required 
information and follows the code of conduct prescribed in the Corporate Governance mandatory compliances. Form the following table 1, it was found that the meetings and the frequency of the meetings i.e. the gap between two meetings shows that the selected banks are strictly following the codes of conduct and they are regularly conducting the meetings.

The following Corporate governance disclosures of the selected banks confirms the compliances of such issues:

1. Arrangement of committees of Board of Directors

2. Board of Directors and Senior Management Personnel Code of conduct.

3. Whistle Blower Policy establishment of vigil tool details

4. Basis for the payments to non-executive directors

5. Policy on dealing with related party transactions

6. Material subsidiaries policy

7. Company and its business details
8. Appointment of Directors and their terms and conditions.

9. Listed company old name and new name.

10. Agreements with the media companies and/or their associates and the details.

11. Shareholding pattern

12. Financial results

13. Details for grievance redressal such as Email address.

Consequently it can be noticed that all the selected banks are very much affirmative in the following committees' and reports' governance practices:

1. Composition of Board of Directors

2. Audit Committee

3. Nomination \& remuneration committee

4. Stakeholders relationship committee

5. Risk management committee

6. Reports of the above committees

Table.1. Meetings and their frequency between the meetings of the Selected Banks

\begin{tabular}{|l|l|l|l|l|l|l|}
\hline MEETING/ BANKS & SBI & IB & CANARA & IDBI & ICICI & HDFC \\
\hline $\begin{array}{l}\text { Board of directors' } \\
\text { meeting }\end{array}$ & 4 & 4 & 4 & 4 & 4 & 2 \\
\hline $\begin{array}{l}\text { Two consecutive } \\
\text { meetings' maximum gap } \\
\text { (in days) }\end{array}$ & 34 & 41 & 28 & 41 & 55 & 46 \\
\hline Audit committee meeting & 5 & 5 & 4 & 4 & 4 & 5 \\
\hline $\begin{array}{l}\text { Two consecutive } \\
\text { meetings' maximum gap } \\
\text { (in days) }\end{array}$ & 36 & 41 & 28 & 41 & 49 & 46 \\
\hline
\end{tabular}

Source: Sample study 
Table. 2. Corporate Governance compliance of the Selected Banks 
Table.3. Corporate Governance affirmation of the Selected Banks

\begin{tabular}{|l|l|c|}
\hline 1 & Board of Directors' composition & Yes \\
\hline 2 & Composition of the following committees & Yes \\
\hline A & Audit Committee & Yes \\
\hline B & Nomination \& remuneration committee & Yes \\
\hline C & Stakeholders relationship committee & Yes \\
\hline D & Risk management committee & Yes \\
\hline 3 & Committee members made aware of their powers, role and responsibilities & Yes \\
\hline 4 & Conducting all meetings including meetings of the Board of Directors & Yes \\
\hline 5 & $\begin{array}{l}\text { Presentation of the previous report submitted which has been placed before Board of } \\
\text { Directors with their comments/observations/advice }\end{array}$ \\
\hline
\end{tabular}

Source: Sample study

Table. 4.Financial Ratios of the Selected Banks

\begin{tabular}{|c|c|c|c|c|c|c|}
\hline FINANCIAL RATIOS & SBI & $\begin{array}{l}\text { INDIAN } \\
\text { BANK }\end{array}$ & $\begin{array}{l}\text { ICICI } \\
\text { BANK }\end{array}$ & $\begin{array}{l}\text { HDFC } \\
\text { BANK }\end{array}$ & $\begin{array}{l}\text { CANARA } \\
\text { BANK }\end{array}$ & $\begin{array}{l}\text { IDBI } \\
\text { BANK }\end{array}$ \\
\hline \multicolumn{7}{|l|}{ Investment Valuation Ratios } \\
\hline Dividend Per Share & 9.675 & 4.1 & 11.1 & 9.67 & 7.5 & 1.75 \\
\hline Operating Profit Per Share $(\square)$ & 57.324 & 40.244 & 29.628 & 47.364 & 48.264 & 12.428 \\
\hline Net Operating Profit Per Share $(\square)$ & 541.71 & 337.322 & 199.798 & 236.542 & 768.86 & 160.124 \\
\hline \multicolumn{7}{|l|}{ Profitability Ratios } \\
\hline Interest Spread & 6.15 & 6.238 & 7.124 & 7.756 & 6.274 & 6.662 \\
\hline Net Profit Margin & 5.13 & 6.884 & 20.452 & 20.974 & -0.314 & -3.362 \\
\hline Return on Long Term Fund (\%) & 87.83 & 92.916 & 53.43 & 69.366 & 122.214 & 95.2 \\
\hline Return on Net Worth (\%) & 5.922 & 8.15 & 12.214 & 17.118 & -0.198 & -5.606 \\
\hline Return on Assets & 471.29 & 284.176 & 333.562 & 294.962 & 486.398 & 122.948 \\
\hline \multicolumn{7}{|l|}{ Management Efficiency Ratios } \\
\hline Interest Income / Total Funds & 7.6 & 8.118 & 7.734 & 8.916 & 7.938 & 8.026 \\
\hline Non-Interest Income / Total Funds & 1.298 & 0.904 & 2.064 & 1.646 & 1.032 & 1.038 \\
\hline Operating Expense / Total Funds & 1.906 & 1.51 & 1.76 & 2.434 & 1.392 & 1.104 \\
\hline Profit Before Provisions / Total Funds & 1.992 & 1.78 & 3.156 & 3.276 & 1.474 & 1.594 \\
\hline Net Profit / Total Funds & 0.792 & 0.558 & 1.586 & 1.868 & 0.008 & -0.24 \\
\hline Loans Turnover & 0.122 & 0.126 & 0.136 & 0.144 & 0.13 & 0.136 \\
\hline Total Income / Capital Employed (\%) & 8.896 & 9.022 & 9.8 & 10.564 & 8.974 & 9.06 \\
\hline Interest Expended / Capital Employed (\%) & 4.92 & 5.654 & 4.782 & 4.738 & 6.05 & 6.306 \\
\hline Total Assets Turnover Ratios & 0.076 & 0.08 & 0.078 & 0.088 & 0.08 & 0.08 \\
\hline Asset Turnover Ratio & 0.082 & 0.082 & 0.08 & 0.096 & 0.08 & 0.08 \\
\hline \multicolumn{7}{|l|}{ Profit And Loss Account Ratios } \\
\hline Interest Expended / Interest Earned & 64.764 & 69.444 & 61.79 & 53.05 & 75.954 & 78.618 \\
\hline Other Income / Total Income & 14.638 & 10.1 & 21.04 & 15.592 & 11.656 & 11.448 \\
\hline Operating Expense / Total Income & 21.402 & 16.776 & 17.944 & 23.05 & 15.642 & 12.218 \\
\hline \multicolumn{7}{|l|}{ Balance Sheet Ratios } \\
\hline Capital Adequacy Ratio & 12.758 & 13.07 & 17.498 & 15.562 & 11.242 & 11.788 \\
\hline Advances / Loans Funds (\%) & 76.36 & 73.456 & 74.222 & 82.626 & 68.492 & 65.73 \\
\hline \multicolumn{7}{|l|}{ Debt Coverage Ratios } \\
\hline Credit Deposit Ratio & 81.808 & 73.394 & 101.69 & 83.412 & 69.698 & 82.006 \\
\hline Investment Deposit Ratio & 31.938 & 30.926 & 49.648 & 33.396 & 30.276 & 41.694 \\
\hline Cash Deposit Ratio & 6.534 & 4.59 & 6.758 & 6.782 & 4.504 & 5.256 \\
\hline Total Debt to Owners Fund & 14.326 & 13.916 & 6.66 & 8.442 & 19.018 & 15.37 \\
\hline Financial Charges Coverage Ratio & 1.422 & 1.338 & 1.688 & 1.72 & 1.258 & 1.258 \\
\hline $\begin{array}{l}\text { Financial Charges Coverage Ratio Post } \\
\text { Tax }\end{array}$ & 1.098 & 1.114 & 1.352 & 1.422 & 1.004 & 0.966 \\
\hline Leverage Ratios & & & & & & \\
\hline
\end{tabular}




\begin{tabular}{|l|l|l|l|l|l|l|}
\hline Current Ratio & 0.058 & 0.036 & 0.098 & 0.054 & 0.042 & 0.07 \\
\hline Quick Ratio & 12.254 & 24.444 & 13.386 & 12.884 & 24.196 & 22.232 \\
\hline Cash Flow Indicator Ratios & & & & & & \\
\hline Dividend Payout Ratio Net Profit & 20.115 & 17.26 & 27.65 & 19.51 & 20.405 & 17.61 \\
\hline Earning Retention Ratio & 88.674 & 86.194 & 77.88 & 88.294 & 91.838 & 89.43 \\
\hline Earnings Per Share & 84.526 & 23.118 & 42.02 & 49.78 & 3.826 & 3.978 \\
\hline
\end{tabular}

Source: Sample study

Accounting disclosure is raised to a particularly high level of importance for banking organisations and they are inherently more opaque. For bank investors and other stakeholders, accounting reports are almost the sole source of information. Bank investors can acquire a sense of a bank's performance and asset quality only from accounting numbers, where banks own few physical and visible assets. The main activity of the Banks is to provide loans and to take risk.Financial disclosures of the banks does not provide enough financial information and the financial stability of the banks to the investors.

\section{DATA ANALYSIS AND INTERPRETATION -II}

\section{Financial Disclosures}

Disclosures on general profits, loans, interest on exceptional deposits and so forth., are much less informative for banks and the maximum critical facts typically lies inside the details of the sources of profits and prices or exceptional of assets. These records are want to the financial institution buyers to make judgments on which fees are routine and on which earnings are sustainable. Such financial disclosures in well-known include 35 factors termed as Dividend Per Share, Operating Profit Per Share, Net Operating Profit Per Share, Interest Spread, Net Profit Margin, Return on Long Term Fund, Return on Net Worth, Return on Assets, Interest Income / Total Funds, NonInterest Income / Total Funds, Operating Expense / Total Funds, Profit Before Provisions / Total Funds, Net Profit / Total Funds, Loans Turnover, Total Income / Capital Employed, Interest Expended / Capital Employed, Asset Turnover Ratio , Interest Expended / Interest Earned, Other
Income / Total Income, Operating Expense / Total Income, Capital Adequacy Ratio, Advances / Loans Funds, Debt Coverage Ratios, Credit Deposit Ratio, Investment Deposit Ratio, Cash Deposit Ratio, Total Debt to Owners Fund, Financial Charges Coverage Ratio, Financial Charges Coverage Ratio Post Tax, Current Ratio, Quick Ratio, Cash Flow Indicator Ratios, Dividend Payout Ratio Net Profit, Earning Retention Ratio and Earnings Per Share.

\section{Profitability}

Net profit to Revenue is the measurement for Profitability, which is a financial ratio that is used as an assessment technique in order to evaluate the capability of a bank to generate earnings. Lesser profits may provide management with an incentive to exaggerate revenues or to undervalue the expenses.

\section{Capital turnover}

Revenue to total assets is the ratio measurement for Capital turnover. Turnover is the sales generating power of the assets of the firm. In competitive situations, this ratio measures the management's ability.

Table . 5 Capital Adequacy Ratio of the Selected Banks

\begin{tabular}{|l|l|l|l|l|l|}
\hline Capital Adequacy Ratio & $\begin{array}{l}\text { Mar } \\
\text { 13 }\end{array}$ & $\begin{array}{l}\text { Mar } \\
\text { '14 }\end{array}$ & $\begin{array}{l}\text { Mar } \\
\text { '15 }\end{array}$ & $\begin{array}{l}\text { Mar } \\
\text { '6 }\end{array}$ & $\begin{array}{l}\text { Mar } \\
17\end{array}$ \\
\hline SBI & 12.96 & 12 & 13.12 & 13.11 & 12.6 \\
\hline INDIAN BANK & 13.1 & 12.86 & 13.2 & 13.64 & 12.55 \\
\hline ICICI BANK & 18.74 & 17.7 & 17.02 & 16.64 & 17.39 \\
\hline HDFC BANK & 16.07 & 16.79 & 15.53 & 14.6 & 14.82 \\
\hline CANARA BANK & 10.63 & 10.56 & 11.08 & 12.86 & 11.08 \\
\hline IDBI BANK & 13.13 & 11.68 & 11.76 & 11.67 & 10.7 \\
\hline
\end{tabular}

Figure 1. Graphical Representation of Capital Adequacy Ratio

\section{CAPITAL ADEQUACY RATIO}

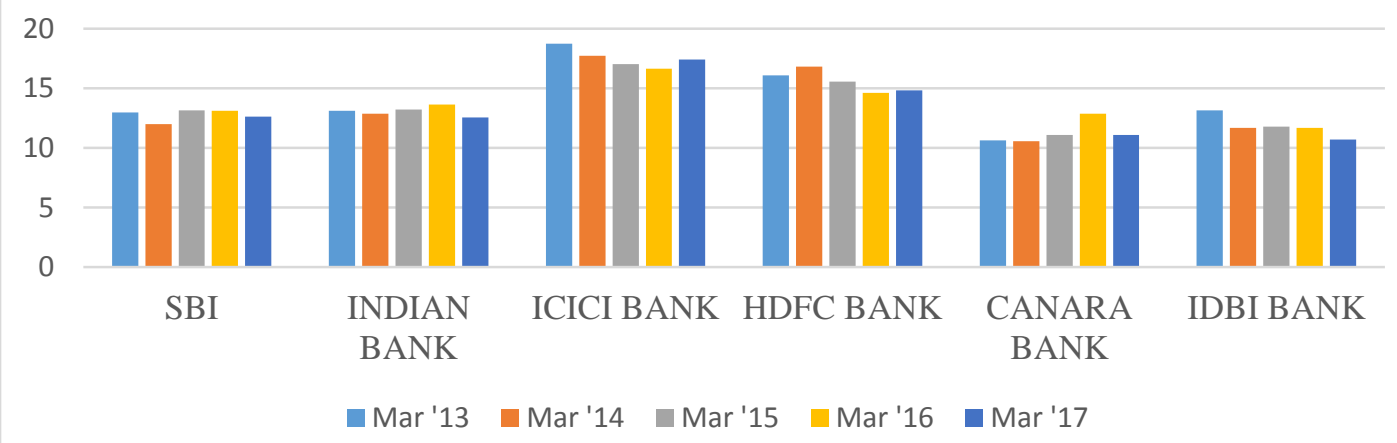


International Conference on Recents Advancements in Engineering and Technology (ICRAET-18) |15th and 16th March 2019|Siddhartha Institute of Technology \& Sciences, Telangana, India

Table . 6 NPA to Advances of the Selected Banks

\begin{tabular}{|c|c|c|c|c|c|}
\hline NPA toAdvances & $\begin{array}{l}\text { Mar } \\
' 13 \\
\end{array}$ & $\begin{array}{l}\text { Mar } \\
\text { '14 } \\
\end{array}$ & $\begin{array}{l}\text { Mar } \\
' 15 \\
\end{array}$ & Mar '16 & Mar '17 \\
\hline SBI & 4.75 & 4.95 & 4.25 & 6.5 & 6.9 \\
\hline INDIAN BANK & 3.33 & 3.67 & 4.4 & 6.66 & 7.45 \\
\hline ICICI BANK & 3.22 & 3.03 & 3.78 & 5.82 & 8.74 \\
\hline HDFC BANK & 0.85 & 0.91 & 0.89 & 0.92 & 1.04 \\
\hline CANARA BANK & 2.57 & 2.49 & 3.89 & 9.4 & 9.63 \\
\hline IDBI BANK & 3.22 & 4.9 & 5.88 & 10.98 & 21.25 \\
\hline
\end{tabular}

Figure 2. Graphical Representation of NPA to Advances

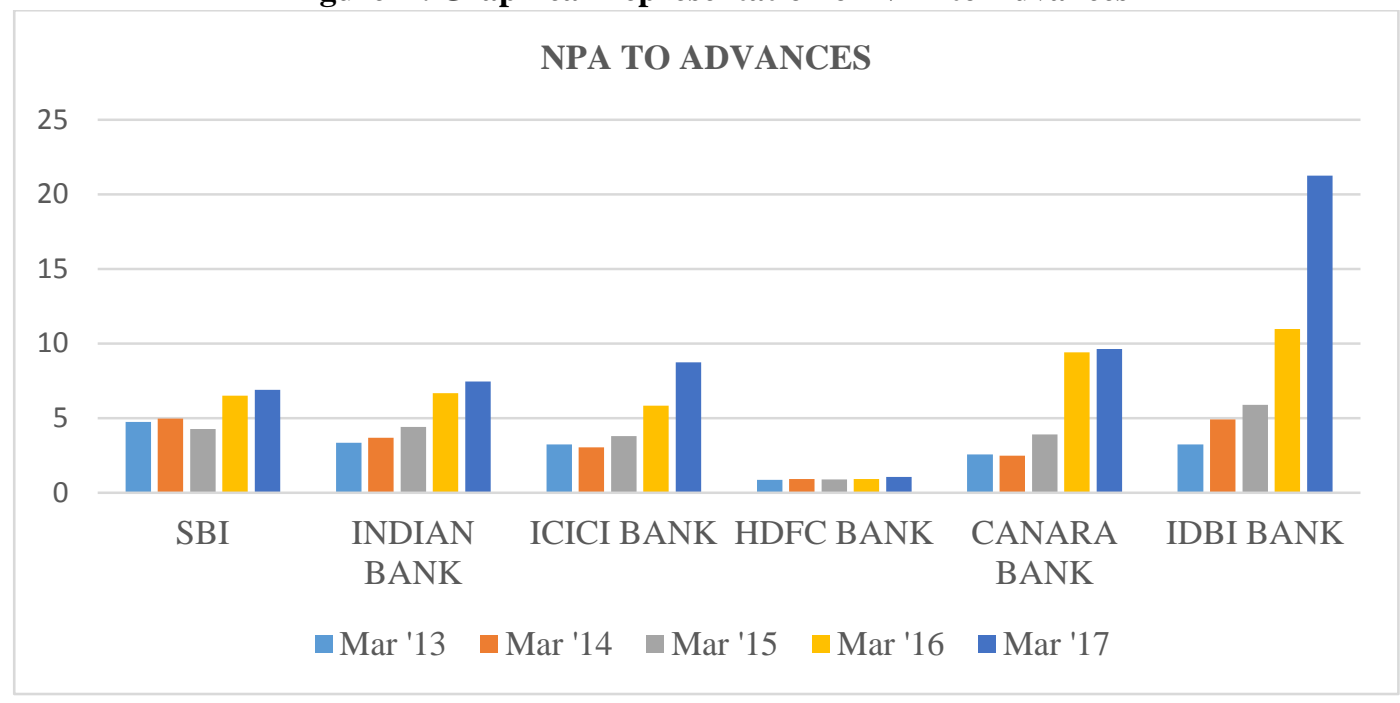

Figure. 3. Graphical Representation of Return on Assets

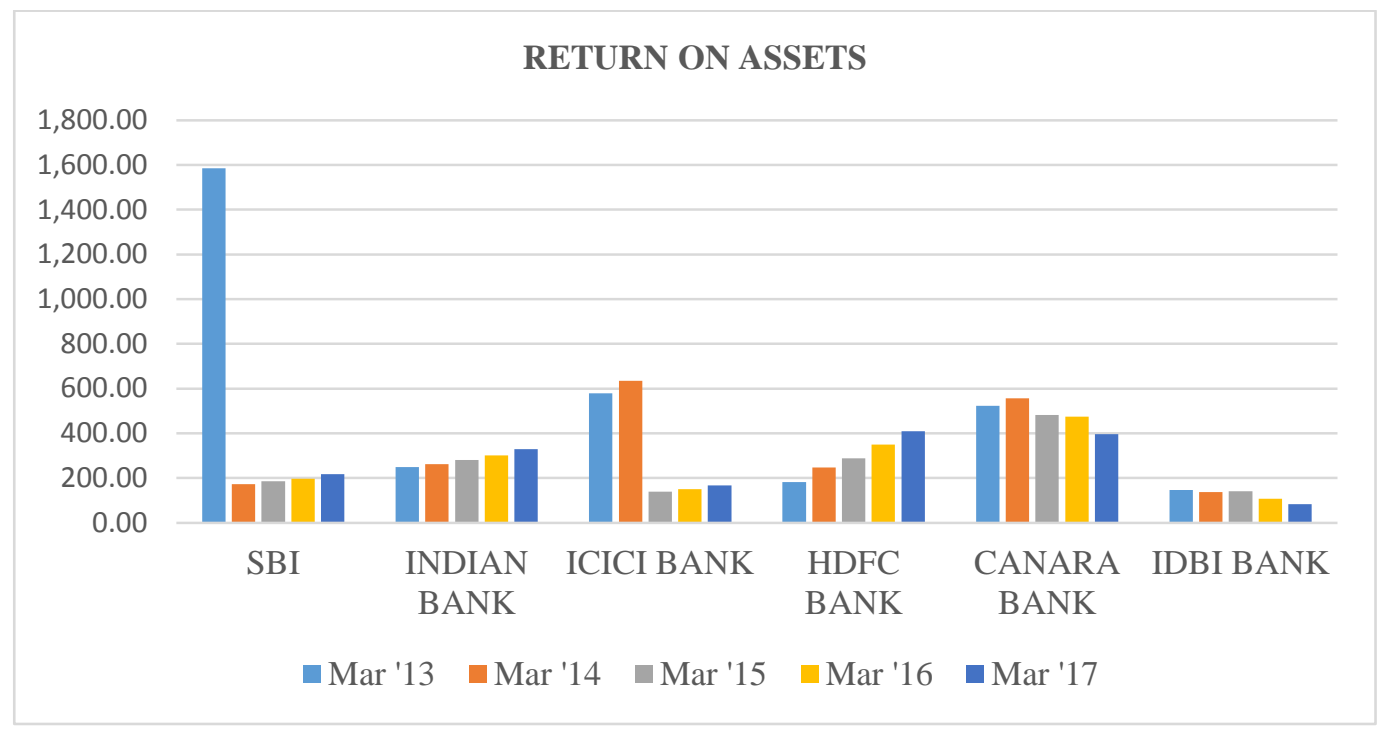


Table . 7Return on Assets of the Selected Banks

\begin{tabular}{|l|l|l|l|l|l|}
\hline Return on Assets & Mar '13 & Mar '14 & Mar '15 & Mar '16 & Mar '17 \\
\hline SBI & $1,584.34$ & 172.04 & 185.85 & 196.53 & 217.69 \\
\hline INDIAN BANK & 248.16 & 261.46 & 280.6 & 301.1 & 329.53 \\
\hline ICICI BANK & 578.65 & 634.6 & 138.72 & 149.47 & 166.37 \\
\hline HDFC BANK & 181.23 & 247.39 & 287.47 & 349.12 & 409.6 \\
\hline CANARA BANK & 522.96 & 556.68 & 481.75 & 474.01 & 396.59 \\
\hline IDBI BANK & 146.11 & 136.7 & 141.24 & 107.41 & 83.28 \\
\hline
\end{tabular}

Table . 8Share Prices of the Selected Banks

\begin{tabular}{|c|c|c|c|c|c|}
\hline Share Prices & Mar '13 & Mar '14 & Mar '15 & Mar '16 & Mar '17 \\
\hline SBI & 269 & 244 & 188 & 159.85 & 191.46 \\
\hline INDIAN BANK & 209.9 & 116.45 & 220.2 & 240.4 & 325.05 \\
\hline ICICI BANK & 199.72 & 320.91 & 237.7 & 232.09 & 314 \\
\hline HDFC BANK & 646.6 & 866.95 & 1083 & 1088.6 & 1885.16 \\
\hline CANARA BANK & 274.54 & 436.44 & 289.7 & 233.73 & 362.4 \\
\hline IDBI BANK & NA & 70.6 & 93.4 & 68.65 & 59.75 \\
\hline
\end{tabular}

Figure 4. Graphical Representation of Share Prices

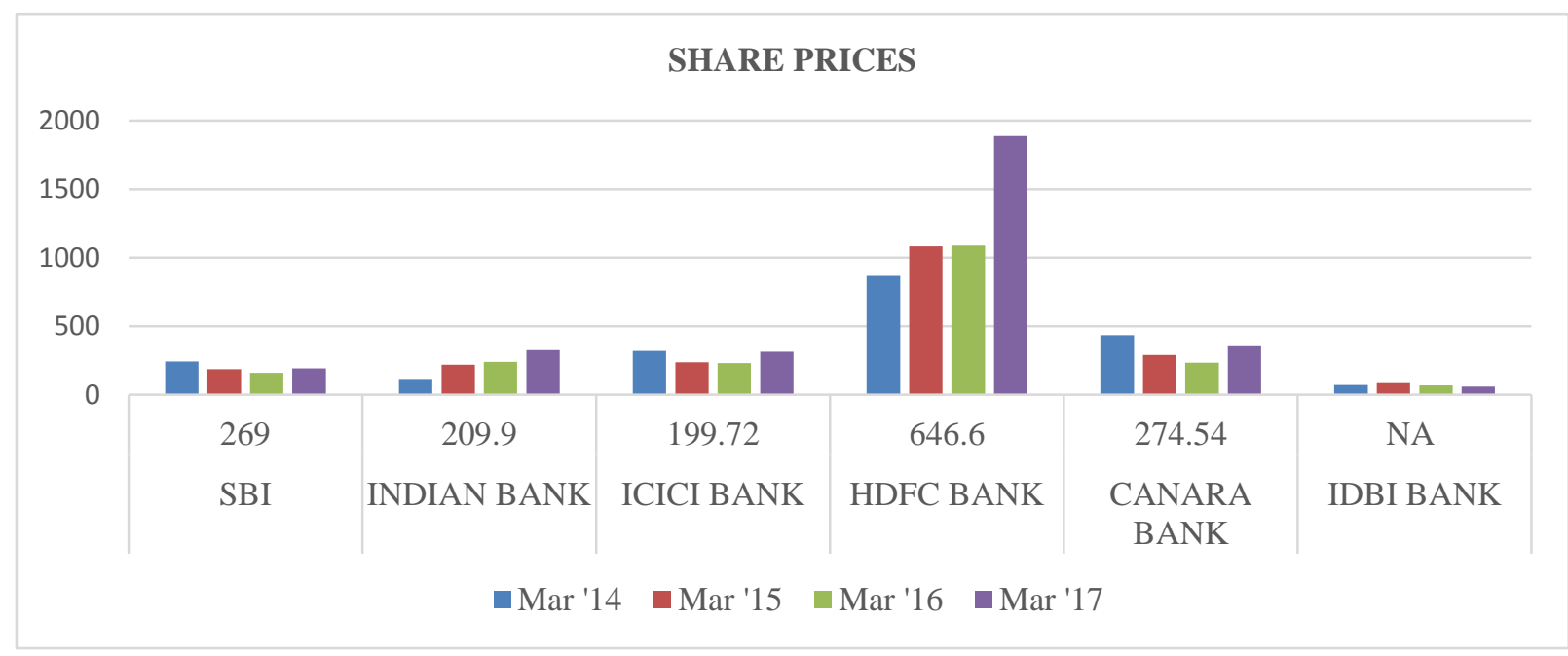

Table. 9 Earnings Per Share of the Selected Banks

\begin{tabular}{|c|c|c|c|c|c|}
\hline $\begin{array}{c}\text { Earnings Per } \\
\text { Share }\end{array}$ & Mar'13 & Mar'14 & Mar'15 & Mar'16 & Mar'17 \\
\hline SBI & 360.83 & 43.17 & 12.82 & 13.15 & -7.34 \\
\hline INDIAN BANK & 24.37 & 20.93 & 14.81 & 29.27 & 26.21 \\
\hline ICICI BANK & 72.22 & 85.04 & 19.28 & 16.73 & 16.83 \\
\hline HDFC & 35.34 & 40.76 & 48.64 & 56.78 & 67.38 \\
\hline CANARA BANK & 52.86 & 56.87 & -51.8 & 18.78 & -57.58 \\
\hline IDBI BANK & 14.7 & 6.99 & 5.45 & 17.8 & -25.05 \\
\hline
\end{tabular}


International Conference on Recents Advancements in Engineering and Technology (ICRAET-18) |15th and 16th March 2019|Siddhartha Institute of Technology \& Sciences, Telangana, India

Figure 5. Graphical Representation of Earnings Per Share

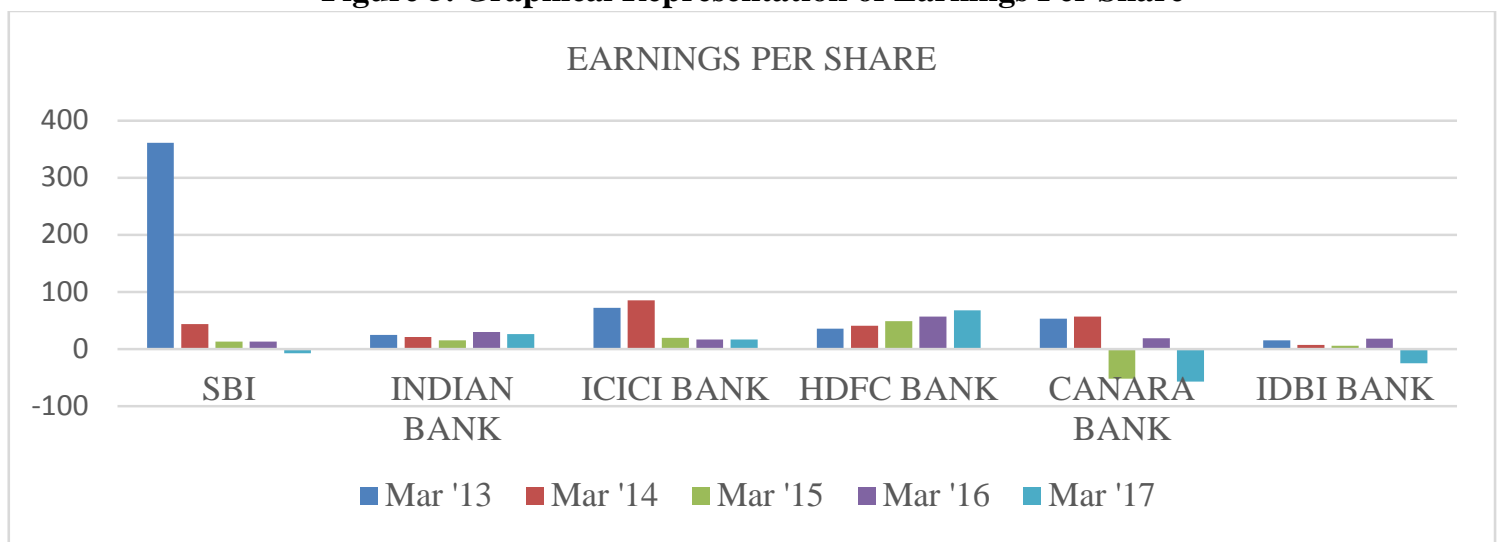

\section{Asset Composition}

Composition of Assets are measured by Current Assets (inventory, receivables, etc.,) to Total assets. Accounting numbers of these Assets are anticipated to be positive values. This shows that the higher the values, higher the risk of overstatements and subsequently it leads to an increase in the likelihood of fraud.

\section{Liquidity}

Measurement of Liquidity is the ratio betweenWorking Capital to Total Assets. Firms with a very low liquidity ratio indicates that they cannot settle their obligations. The Financial ratios of the selected banks for the study period as predicted in the Table 4. Which shows that all the selected Banks are financially sound. Only Canara bank and IDBI bank show negative Net Profit margin and Return on Net Worth, while all other figure as shown in the table are positive ratios. Hence, with regard to all other ratios of all the banks reflect positive results and favourable results also.

\section{DATA ANALYSIS AND INTERPRETATION - III}

\section{Correlative Analysis}

The third goal of the take a look at is to discover whether there may be any dating among the Corporate Governance disclosures and key economic ratios of the selected banks. During the look at duration in which the chosen banks have followed the recommendations framed by using RBI regarding Corporate Governance, their overall economic performance of the selected banks studied thru correlation analysis.

- Correlation between CAR and Share Prices (SP) of 6 banks over five years offers the following results:

Cases of a positive relationship between CAR and Share Price - 1

Cases of poor correlation between CAR and Share Price five

The results confirmed that CAR and proportion charges are negatively correlated in 5 out of 6 cases. The have a look at unearths that during most of the cases, an improvement in CAR does not bring about higher asset exceptional, better returns, and share fees.

- Correlation between CAR and Earnings Per Share Prices (EPS) of 6 banks over 5 years offers the following results:

Cases of wonderful correlation between CAR and EPS - 4
Examples of weak correlation among CAR and EPS -2

The effects confirmed that CAR and EPS are correlated in four out of 6 instances. The look at unearths that during the maximum of the instances, an improvement in CAR is contemplated in extended profitability and actual wealth growth of shareholders.

- Correlation among NPA and Share Prices (SP) of 6 banks for 5 years offers the subsequent effects:

Cases of the advantageous relationship between NPA and SP - 3

Cases of terrible correlation between NPA and SP -3

The effects confirmed that NPS and SP are equally definitely in addition to negatively correlated in 3 out of 6 cases. The examine unearths that during most of the cases, any growth in the NPA ratio indicates that an same deteriorating asset quality and a consequent fall in share fees.

- Correlation between NPA and Earnings Per Share (EPS) of 6 banks over a length of five years offers the following results:

Cases of effective correlation between NPA and EPS three

Cases of bad correlation between NPA and EPS -three

The consequences confirmed that NPS and EPS are equally positively as well as negatively correlated in 3 out of 6 cases. The examine unearths that in most of the cases, any reduction in NPA results in lower profitability and EPS.

- Correlation among ROA and Share Prices (SP) of 6 banks over a length of five years gives the subsequent consequences:

Cases of advantageous correlation among ROA and SP 6

Cases of bad correlation between ROA and SP -zero*

(*In these kind of cases, correlation coefficient changed into much less than $2 \%$ )

The results confirmed that ROA and SP are undoubtedly correlated in all of the 6 instances. The have a look at finds that in most of the cases both ROA and SO circulate together, and accordingly, any development in ROA effects

Published By:

Blue Eyes Intelligence Engineering

$\&$ Sciences Publication 
in boom in normal shareholders wealth meditated in better share expenses.

- Correlation between ROA and Earnings Per Share (EPS) of 6 banks over a duration of 5 years gives the subsequent consequences:

Cases of superb correlation between ROA and EPS - 6

Cases of terrible correlation between ROA and EPS - $0 *$

The outcomes showed that ROA and EPS are positively correlated in all of the 6 cases. The take a look at reveals that during maximum of the instances, they pass collectively and any development in ROA translates into greater returns on capital and enhanced EPS.

- Correlation between SP and Earnings Per Share (EPS) of 6 banks over a length of five years gives the following outcomes:

Cases of wonderful correlation between SP and EPS - 6

Cases of negative correlation between SP and EPS - zero*

The results confirmed that SP and EPS are undoubtedly correlated in all of the 6 instances. The observe reveals that in most of the cases they flow together in fine tandem.

Table. 10. Correlationof the Ratios (CAR, NPA And ROA) with Share Price and EPS

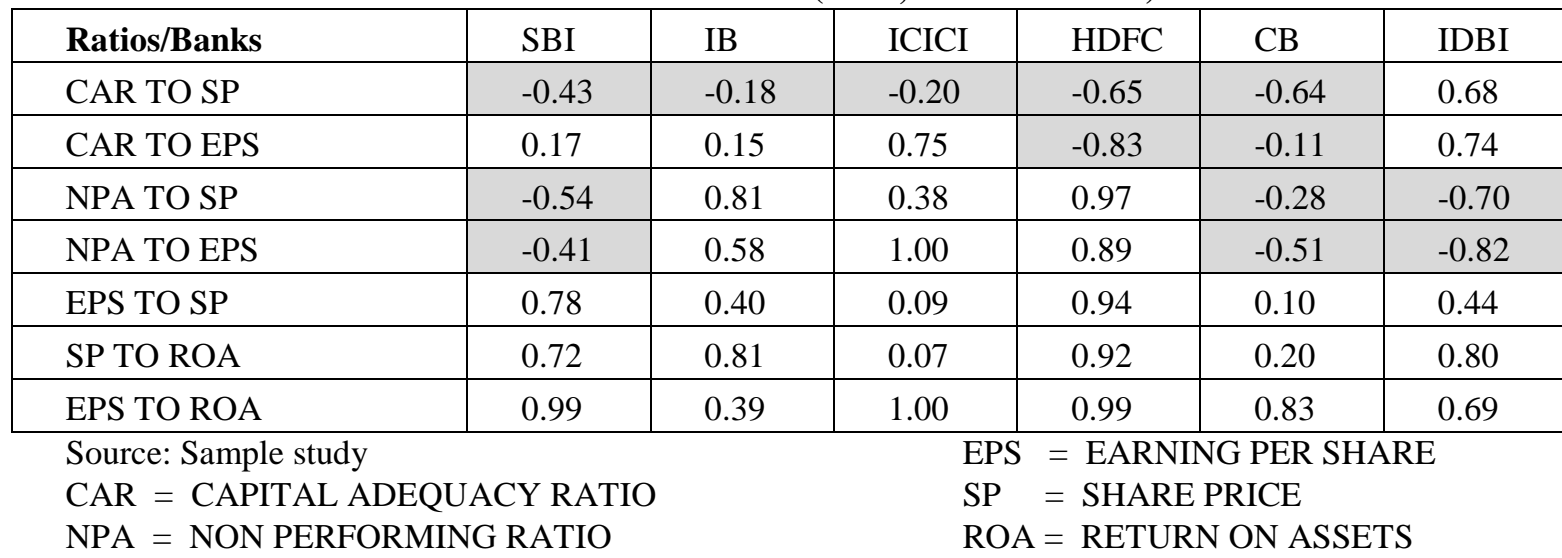

Source: Sample study

CAR $=$ CAPITAL ADEQUACY RATIO

NPA $=$ NON PERFORMING RATIO

$$
\begin{aligned}
& \text { EPS }=\text { EARNING PER SHARE } \\
& \text { SP }=\text { SHARE PRICE } \\
& \text { ROA }=\text { RETURN ON ASSETS }
\end{aligned}
$$

\begin{tabular}{|c|c|c|c|c|c|}
\hline RATIOS & $\begin{array}{l}\text { EXPECTED } \\
\text { CORRELATION }\end{array}$ & $\begin{array}{l}\text { ACTUAL } \\
\text { POSITIVE }\end{array}$ & $\begin{array}{l}\text { ACTUAL } \\
\text { NEGATIVE }\end{array}$ & CONCLUSION & $\begin{array}{l}\text { HYPOTHESIS } \\
\text { PROVED/NOT }\end{array}$ \\
\hline $\begin{array}{l}\text { CAR TO } \\
\text { SP }\end{array}$ & Positive & 1 & 5 & $\begin{array}{l}\text { Reduction of high risk assets } \\
\text { does not results in rise in } \\
\text { share prices }\end{array}$ & No \\
\hline $\begin{array}{ll}\text { CAR } & \text { TO } \\
\text { EPS } & \end{array}$ & Positive & 4 & 2 & $\begin{array}{l}\text { Reduction of risk profile } \\
\text { assets induces boosted } \\
\text { shareholders earnings }\end{array}$ & Yes \\
\hline $\begin{array}{ll}\text { NPA } & \text { TO } \\
\text { SP } & \end{array}$ & Negative & 3 & 3 & $\begin{array}{l}\text { Increase in asset quality does } \\
\text { not affect earnings and share } \\
\text { prices }\end{array}$ & No \\
\hline $\begin{array}{ll}\text { NPA } & \text { TO } \\
\text { EPS } & \end{array}$ & Negative & 3 & 3 & $\begin{array}{l}\text { Profitability and performance } \\
\text { of Banking sector does not get } \\
\text { affected by decrease in non- } \\
\text { performing assets }\end{array}$ & No \\
\hline $\begin{array}{l}\text { ROA TO } \\
\text { SP }\end{array}$ & Positive & 6 & $0 *$ & $\begin{array}{l}\text { Share markets endows any } \\
\text { improvement in productivity } \\
\text { of assets }\end{array}$ & Yes \\
\hline $\begin{array}{ll}\text { ROA } & \text { TO } \\
\text { EPS } & \end{array}$ & Positive & 6 & $\begin{array}{l}0 * \quad \text { (correlation } \\
\text { coefficient less than } \\
2 \%)\end{array}$ & $\begin{array}{l}\text { Higher returns are possible if } \\
\text { more allocation of funds to } \\
\text { profitable assets. }\end{array}$ & Yes \\
\hline $\begin{array}{ll}\text { SP } & \text { TO } \\
\text { EPS } & \end{array}$ & Positive & 6 & $0 *$ & $\begin{array}{l}\text { Present earnings of the Banks } \\
\text { are reflected in Equity markets }\end{array}$ & Yes \\
\hline
\end{tabular}

Table. 11. Summary of the Correlation run over the Selected Banks

From the above two tables, it can be inferred that other than NPA, all other ratios are more than ideal ratio. CAR and ROA are manageable, but NPA reflects lesser than ideal ratio. Thus, banks does not reflect bad quality of loans. But Table. 7 reflects that NPA to SP and EPS is not satisfactory. Hence, banks should concentrate on such issues.

\section{CONCLUSION}

In the last decade there has been development in the financial disclosures and accountability among business firms as mentioned in guidelines of Corporate Governance.
Integration and globilisation of the capital markets and financial markets are the important factors for the rapid developments in this arena. It has also made way to the development of more number of corporate scandals or fraud loans by Banks.

The study investigate the impact of corporate governance disclosure practices and identify the financial ratios efficiency criteria for a successful governance paradigm

Published By:

Blue Eyes Intelligence Engineering

\& Sciences Publication 
accountability. It also aims to study about the financial ratios which are within the RBI trigger level and find out whether there is any impact on the movements of share prices and earnings per share. Empirically, the study using correlation to establish the accountability of the selected banks for the period of 5 years, shows that there is correlated relationship between Return on Assets (ROA) with Share prices and EPS. If there is any movement in ROA, there is enhancement in Share prices and Earning per Share. The same result can be noted with the correlation between Share prices and Earnings per share. These two variable also closely related each other and results are as expected has derived. The results also gives a caution to the selected banks that the Non-Performing Assets are not satisfactory level of ratio.

Without doubt, the greatest responsibility of the banks for the excessive risks which is borne by them is that their management and supervisory directors. Also, economic, legal and ethical issues differentiate the degree of responsibility and severity of the acts/omissions of numerous operators.

Irrespective of the regulatory changes by RBI according to the happenings of the frauds and misappropriations, it is necessary to emphasis the importance of the accountability of all the bank stakeholders. Corporate Governance, particularly in the Banking sector, should ensure that the care and well-being of all banking investors as well as other stakeholders. This corporate impartiality, answerability, accountability and transparency must be symmetric.

\section{REFERENCES}

1. Dr Gursharan Singh Kainth and Jyoti Agnihotri.,Disclosure Practices in Banking Sector of India, Guru Arjan Dev Institute of Development Studies(2012).

2. Gompers, P. A., Ishii, J. L., \& Metrick, A.,Corporate Governance and Equity Prices, Quarterly Journal of Economics,118(1), $107-155$ http://doi.org/10.2139/ssrn.278920(2003).

3. Kar, S.,Corporate Governance Practices in Private Commercial Banks-A Study on Khulna City,International Journal of Economic Behavior and Organization, 2(3), 37. http://doi.org/10.11648/j.ijebo.20140203.12(2014).

4. Liang, D., Lu, C. C., Tsai, C. F., \& Shih, G. A.,Financial ratios and corporate governance indicators in bankruptcy prediction: A comprehensive study,European Journal of Operational Research, 252(2), 561-572. http://doi.org/10.1016/j.ejor.2016.01.012(2016).

5. Mahmood, R., \& Islam, M.,Practices of Corporate Governance in the Banking Sector of Bangladesh,International Journal of Managing Value and Supply Chains, 6(3), 17-29. http://doi.org/10.5121/ijmvsc.2015.6302(2015).

6. Mbanwie, G., \& N, N. E.,Financial Ratios as bankruptcy Indicators: The case of Financially Distressed Firms in Sweden, Msc Thesis, University of Gothenburg(2009).

7. Mülbert, P. O.,Corporate governance of banks, European Business Organization Law Review, 10(3), 411-436. http://doi.org/10.1017/S156675290900411X(2009).

8. Norhafiza, S., \& Ibrahim, S.,The Relationship Between Corporate Governance Disclosures and Balance Sheet Ratios,Gading Business and Management Journal, 11(2), 33-40(2007).
9. Spong, K., \& Sullivan, R. J.., Corporate Governance and Bank Performance,SSRN Electronic Journal. http://doi.org/10.2139/ssrn.1011068(2007).

10. Tiscini, R. - Francesca di Donato., The relation between accounting frauds and corporate governance systems: an analysis of recent scandals, Electronic copy available at: http://ssrn.com/abstract=1392754. Network, 1(March), 1-16. http://doi.org/http://dx.doi.org/10.2139/(2004) 